\title{
TINJAUAN PERTANGGUNGJAWABAN PELAKU TINDAK PIDANA PORNOGRAFI MENURUT UNDANG- UNDANG NOMOR 44 TAHUN 2008 TENTANG PORNOGRAFI
}

\author{
Erinda Sinaga \\ Fakultas Hukum Universitas Riau \\ Email: erinda.sinaga@yahoo.com \\ Mukhlis R. dan Erdiansyah \\ Fakultas HukumUniversitas Riau
}

\begin{abstract}
Pornography has damaged morale of Indonesian people, especially the youth. Pornography happens must have a lot of special attention, especially the enforcement of law and community to cooperate in fighting the pornography. Pornography has been enacted in the Law Number 44 of 2008 on pornography, but has not been able to give the benefit of addressing pornography crimes, because the Law still has a weakness in the system of criminal responsibility and overlap with the ideas such as producing, reproducing for copying, distributing and reselling. There's also a weakness in determining the criminal related to Article 8, 9, and 11 of Pornography Laws, the lack of definition of the word "download" with regard to article 5, that no one is allowed to lend or download pornography as referred to in Article 4 verse (1). Of these weaknesses affect criminal responsibility in the acts of pornography.
\end{abstract}

Keywords: Obligation, Crime, Pornograhphy.

\section{abstrak}

Pornografi telah merusak moral masyarakat Indonesia, khususnya kaum muda. Pornografi yang terjadi harus memiliki banyak perhatian khusus terutama penegakan hukum dan masyarakat untuk bekerja sama dalam memerangi pornografi kejahatan ini. Pornografi telah diberlakukan dalam UU No. 44 Tahun 2008 tentang Pornografi, namun belum mampu memberi manfaat dalam menangani kejahatan di pornografi karena undang-undang pornografi masih memiliki kelemahan dalam sistem akuntabilitas tanggung jawab pidana karena tumpang tindih dengan gagasan seperti membuat rasa memproduksi, mereproduksi untuk menyalin, mendistribusikan, dan memperjualbelikan. Kelemahan juga dalam menentukan pidana terkait dengan Pasal 8, 9 dan 11 Undang-Undang Pornografi, kurangnya definisi kata "unduh" atau "download" yang berkaitan dengan Pasal 5 bahwa tidak 
ada yang diperbolehkan untuk meminjamkan atau mengunduh pornografi sebagaimana dimaksud dalam Pasal 4 ayat (1). dari kelemahan tersumbat sangat mempengaruhi tanggung jawab pidana dalam tindak pornografi.

Kata Kunci: Kewajiban, Kejahatan, Pornografi.

\section{A. Pendahuluan}

Pada era globalisasi seperti saat ini, pornografi disajikan secara bebas tanpa batas oleh oknum-oknum yang tidak bertanggungjawab. Peredaran pornografi hampir menyentuh di berbagai bidang media massa, seperti koran, majalah, tabloid, film, buku, gambar/foto, bahkan tulisan, materi sandiwara, lawak atau dagelan masyarakat. ${ }^{1}$

Secara etimologi pornografi berasal dari dua suku kata, yakni pornos dan grafi. Pornos artinya suatu perbuatan yang asusila (dalam hal yang berhubungan dengan seksual), atau perbuatan yang bersifat tidak senonoh atau cabul, sedangkan grafi adalah gambar atau tulisan, yang dalam arti luas termasuk benda-benda patung, yang isi atau artinya menunjukan atau menggambarkan sesuatu yang bersifat asusila atau menyerang rasa kesusilaan masyarakat. $^{2}$

Sebelum dikeluarkannya Undang-Undang Nomor 44 Tahun 2008 tentang Pornografi, mengenai tindak pidana yang melanggar kesusilaan diatur dalam Pasal 282 Kitab Hukum Undang-Undang Pidana yang berbunyi sebagai berikut:

1) barangsiapa menyiarkan, mempertunjukan atau menempelkan di muka umum tulisan, gambaran atau benda yang telah diketahui isinya melanggar kesusilaan, atau barangsiapa dengan maksud untuk disiarkan, dipertunjukan atau ditempelkan di muka umum, membuat tulisan, gambaran atau benda tersebut, memasukanya ke dalam negeri, atau memiliki persediaan, ataupun barangsiapa secara terang-terangan atau dengan mengedarkan surat tanpa diminta, menawarkanya atau menunjukannya sebagai bisa diperoleh, diancam dengan pidana denda paling tinggi empat ribu lima ratus rupiah;

2) barangsiapa yang menyiarkan, mempertunjukan kepada umum, menempelkan, ataupun untuk disiarkan, dipertunjukan kepada umum atau ditempelkan, memasukan ke dalam negeri atau menyimpan atau dengan terang-terangan menyiarkan tulisan, menawarkan tidak atas permintaan orang atau menunjukan bahwa oleh di dapat tulisan, gambar

\footnotetext{
${ }^{1}$ Vina Dwi Laning, Kenakalan Remaja dan Penangulangannya, (Karanganom: Ciempaka Putih,2008),hlm,38.

2 Adami Chazawi, Tindak Pidana Mengenai Kesopanan, (Malang: PT Grafindo Persada, 2005), hlm, 22.
} 
atau barang yang melanggar kesusilaan, jika ia terus dapat menyangka bahwa tulisan, gambar atau barang itu melanggar kesusilaan dihukum dengan hukuman penjara selama-lamanya sembilan bulan atau benda sebanyak- banyaknya; dan

3) kalau melakukan kejahatan tersebut dalam ayat pertama itu oleh yang berasal dijadikan pekerjaan atau kebiasaan, dapat dijatuhkan hukuman penjara selama-lamanya dua tahun delapan bulan atau denda sebanyakbanyaknya lima ribu rupiah.

Di dalam Pasal 282 ayat (1) dan ayat (2) memiliki perbedaan unsur kesalahannya. Ayat (1) menurut unsur dolus (sengaja) dan pada ayat (2) memuat unsur kelalaian. ${ }^{3}$ Disamping Pasal 282 agar supaya sesuatu perbuatan yang tidak dapat dihukum menurut Pasal 282 masih dapat dipersalahkan menurut Pasal Mengenai pelanggaran kesusilaan terdapat dalam Pasal 532-535 Kitab Undang-Undang Hukum Pidana(KUHP).

Tindak pidana kesusilaan yang ada dalam KUHP tidak dapat menjangkau tindak pidana pornografi yang semakin kompleks terjadi. Pada tahun 2008 diundangkanlah Undang-Undang Nomor 44 Tahun 2008 tentang Pornografi. Sebagai landasan filosofi dari Undang-Undang Pornografi tersebut sebagaimana ditegaskan di dalam Konsideran Undang-Undang Pornografi adalah bahwa negara Indonesia adalah negara hukum yang berdasarkan Pancasila dengan menjunjung tinggi nilai-nilai moral, etika, akhlak mulia, dan kepribadian luhur bangsa, beriman dan bertakwa kepada Tuhan Yang Maha Esa, menghormati kebinekaan dalam kehidupan bermasyarakat, berbangsa, dan bernegara.

Berdasarkan Pasal 1 Undang-Undang Nomor 44 Tahun 2008 tentang Pornografi, Pornografi diartikan:

"Sebagai gambar, sketsa, ilustrasi, foto, tulisan, suara, bunyi, gambar bergerak, animasi, kartun, percakapan, gerak tubuh, atau bentuk pesan lainnya melalui berbagai bentuk media komunikasi dan/atau pertunjukan di muka umum, yang memuat kecabulan atau eksploitasi seksual yang melanggar norma kesusilaan dalam masyarakat".

Semakin berkembang zaman semakin berkembangnya juga modus orang untuk melakukan tindak pidana pornografi yang banyak dilakukan melalui sarana media elektronik seperti handphone yang tidak diatur dalam Kitab Undang-Undang Hukum Pidana, sehingga penegakan hukumnya dibantu dengan adanya Undang-Undang Nomor 11 Tahun 2008 tentang ITE Pasal 27 ayat (1) berbunyi "Setiap orang dengan sengaja dan tanpa hak mendistribusikan dan/atau mentransmisikan dan/atau membuat dapat

\footnotetext{
${ }^{3}$ Leden Marpaung, Kejahatan Terhadap Kesusilaan, (Jakarta: Sinar Grafika,2008),hlm,37.
} 
diaksesnya Informasi Elektronik dan/atau dokumen Elektronik yang memiliki muatan yang melanggar kesusilaan".

Dilihat dari apa yang telah termuat dalam Undang-Undang yang nomor 11 Tahun 2008 mengenai pelanggaran asusila sudah jelas dan tegas untuk mengatur penyebaran pornografi melalui media elektronik dan sanksinya telah tegas. Namun, tidak semua pelanggaran asusila dapat dijangkau oleh Undang-Undang tersebut sehingga masih ada UndangUndang lain yang membantu dalam penegakan hukum terhadap tindak pidana pornografi yaitu :

1. Undang-Undang Nomor 40 Tahun 1999 tentang Pers (kewajiban memberitakan peristiwa dan opini yang menghormati norma agama, rasa kesusilaan masyarakat, asas praduga tak bersalah (Pasal 5 ayat (1)). Larangan memuat iklan yang bertentangan dengan rasa kesusilaan (Pasal 13); dan

2. Undang-Undang Nomor 33 Tahun 2009 tentang Perfilman Pasal 6 huruf (d) Film yang menjadi unsur pokok kegiatan perfilman dan usaha perfilman dilarang mengandung isi yang: menistakan, melecehkan, dan/atau menodai nilai-nilai agama.

Pornografi di Indonesia merupakan masalah serius bagi pemerintah, di mana Associated Press pernah menyatakan bahwa Indonesia akan menjadi surga pornografi berikutnya, karena di Indonesia sekarang ini berbagai informasi maupun gambar-gambar erotis atau sensual dengan mudah bisa diunduh yang hanya untuk sekedar ditonton maupun dinikmati sehingga oleh oknum-oknum tertentu gambar-gambar yang bersifat pornografis tersebut telah pula dikembangkan dan diperniagakan seperti misalnya kita bisa memperoleh dimanapun dan tidak ada pembatasan atas siapapun terutama termasuk VCD-VCD porno dan banyaknya poster-poster yang menunjukan keseksiannya. Tidak dapat berjalan dengan semestinya juga dapat disebabkan karena lemahnya Undang-Undang Nomor 44 Tahun 2008 tentang Pornografi tersebut untuk menjangkau para pelaku tindak pidana. Adapun beberapa Pasal yang memiliki multitafsir dalam Undang-Undang tersebut yaitu Pasal 8 yang menggunakan unsur "dengan sengaja" Unsur "dengan sengaja" merupakan unsur subjektif, di mana di dalam sistem peradilan pidana khususnya di dalam pemeriksaan di depan sidang, Jaksa Penuntut Umum (JPU) wajib membuktikan bahwa perilaku pelaku memenuhi unsur "dengan sengaja" (dolus/opzet atau kesengajaan) tersebut. Dalam penjelasan dari Pasal 32 Undang-Undang Nomor 44 tentang Pornografi 2008 ternyata melakukan pengecualian dalam penyimpanan dan memiliki barang pornografi. Dengan menyebutkan bahwa larangan "memiliki atau menyimpan" tidak termasuk untuk dirinya sendiri dan kepentingan sendiri. Kalimat tersebut kembali menimbulkan bias hukum. 
Berbicara mengenai tindak pidana pornografi yang sering terjadi di lingkungan masyarakat semua tidak terlepas dari pertanggungjawaban pidana untuk mempertanggungjawabkan perbuatan pidana. Dalam sistem hukum yang dianut oleh Indonesia terdapat asas "Gen Straf Zonder Schuld" yaitu tiada pidana tanpa kesalahan sebagai dasar untuk meminta pertanggungjawaban seseorang atau sesuatu badan hukum. Untuk itu, perlu untuk diketahui bagaimana bentuk pertanggungjawaban pelaku tindak pidana menurut Undang-Undang Nomor 44 Tahun 2008 tentang Pornografi. 1) Bagaimanakah pertanggungjawaban pelaku tindak pidana pornografi menurut Undang-Undang Nomor 44 Tahun 2008 tentang Pornografi?; dan 2) Bagaimanakah kelemahan sistem pertanggungjawaban pelaku tindak pidana pornografi menurut Undang-Undang Nomor 44 Tahun 2008 tentang Pornografi?

\section{B. Pembahasan}

\section{Pertanggungjawaban Pelaku Tindak Pidana Pornografi dalam Undang-Undang Nomor 44 Tahun 2008 tentang Pornografi}

Pornografi merupakan suatu tindak pidana yang sudah lama berkembang di Indonesia. Pornografi secara harfiah berarti "tulisan tentang

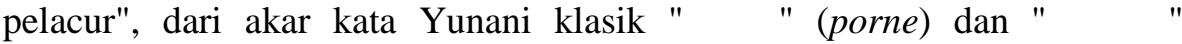
(graphein). Pada awalnya adalah sebuah eufemisme dan secara harfiah berarti (sesuatu yang) dijual. Kata ini berasal dari dari istilah Yunani untuk orang-orang yang mencatat "pornoai", atau pelacur-pelacur terkenal atau yang mempunyai kecakapan tertentu dari Yunani kuno. ${ }^{4}$

Di dalam hukum, tanggungjawab atau pertanggungjawaban pidana berkaitan dengan dasar untuk dapat memberikan sanksi kepada pelaku pelanggaran. Di dalam hukum pidana pertanggung jawaban dikenal dengan konsep "liability". Setiap orang yang melakukan kesalahan dalam hukum pidana dapat dimintai pertanggungjawaban atas perbuatan yang dilakukannya. Oleh karena seseorang tidak dapat diminta pertanggungjawaban jika orang itu tidak melakukan suatu kesalahan yang dilarang dalam hukum pidana suatu ancaman pidana. Akan terasa sangat tidak adil jika seseorang harus bertanggungjawab atas perbuatan yang tidak dilakukannya. Dasar adanya suatu perbuatan pidana adalah asas legalitas, sedangkan dasar dapat dipidananya seseorang adalah atas dasar kesalahan.

Pertanggungjawaban adalah kewajiban memberikan jawaban yang merupakan perhitungan atas suatu hal yang terjadi dan kewajiban untuk memberikan pemulihan atas kerugian yang mungkin ditimbulkannya. Sedangkan pidana didefinisikan sebagai suatu penderitaan yang sengaja dijatuhkan atau diberikan oleh negara kepada seseorang atau beberapa orang

\footnotetext{
${ }^{4}$ http.//www.WilkipediaBahasaIndnoseiaPornografi.com, diakses, tanggal, 07 Februari 2013.
} 
sebagai akibat hukum (sanksi) atas perbuatan yang telah melanggar hukum. Jadi pertanggungjawaban pidana adalah pertanggungjawaban terhadap suatu perbuatan yang dilakukannya yang telah memenuhi syarat untuk mendapatkan akibat hukum (sanksi).

Kesalahan adalah keseluruhan syarat yang memberi dasar untuk adanya pencelaan pribadi terhadap si pembuat pidana. Kesalahan sangat menentukan akibat dari perbuatan seseorang yaitu penjatuhan pidana. Kesalahan merupakan keadaan jiwa dari si pembuat dengan perbuatannya. Seseorang dapat dikatakan mempunyai kesalahan, jika ia pada waktu melakukan perbuatan pidana, dilihat dari segi masyarakat dapat dicela.

Dengan demikian untuk menentukan adanya kesalahan seseorang harus memenuhi unsur, antara lain:

a. melakukan perbuatan pidana;

b. di atas umur tertentu mampu bertanggung jawab;

c. mempunyai suatu bentuk kesalahan yang berupa kesengajaan atau kealpaan; dan

d. tidak adanya alasan pemaaf.

Ada juga orang yang tidak dapat dimintai pertanggungjawabannya dapat dilihat dari rumusan dalam Kitab Undang-Undang Hukum Pidana Pasal 44:"Barangsiapa melakukan perbuatan yang tidak dapat dipertanggungjawabkan kepadanya, karena jiwanya cacat dalam pertumbuhan atau terganggu karena penyakit, tidak dipidana”.

Dilihat dari rumusan dalam Pasal 44 tersebut bahwa keadaan jiwa yang tidak bertanggungjawab yang sifatnya khusus itu berkaitan erat dengan perbuatanya itu sendiri serta keadaan-keadaan objektif dan/atau subjektif tertentu ketika seseorang itu berbuat. Orang yang tidak mampu bertanggungjawab secara khusus ini adalah:

1. apabila keadaan jiwanya sedemikian rupa sehingga ia tidak bebas untuk menentukan kehendaknya terhadap perbuatan apa yang dilakukan; dan

2. apabila keadaan jiwanya sedemikian rupa sehingga ia tidak mengerti, tidak menginsyafi atas sesuatu perbuatan yang dilakukannya itu sebagai perbuatan tercela.

Berdasarkan ketentuan dalam Kitab Undang-Undang Hukum Pidana orang yang tidak dapat dimintai pertanggungjawaban yaitu :

a. orang yang sakit ingatan (Pasal 44);

b. orang di bawah umur (Pasal 45);

c. melaksanakan perintah jabatan (Pasal 45); dan

d. melaksanakan Undang-Undang (Pasal 50).

Dalam hal ini orang yang dapat dipidana haruslah merupakan orang yang normal akalnya, tidak cacat jiwanya atau tidak hilang ingatan, serta orang tersebut telah dewasa. Tidak dapat dipertanggungjawabkan mengakibatkan tidak dapat dijatuhi pidana. Berarti ketika seseorang tidak 
mampu bertanggung jawab maka proses pertanggungjawabannya berhenti atau tidak dilanjutkan. Orang itu hanya dapat dikenakan sanksi berupa tindakan, tetapi tidak dapat dikenakan pidana. Pertanggungjawaban yang berhubungan erat dengan keadaan batin si pembuat.Oleh karena itu, ada alasan yang menghapus kesalahan dalam hukum pidana yaitu alasan pembenar dan alasan pemaaf. Alasan yang menghilangkan sifat melawan hukum tindak pidana disebut alasan pembenar, dan alasan yang menghapus kesalahan disebut dengan alasan pemaaf.

Alasan-alasan penghapus kesalahan yang umum dikenal dalam Kitab Undang-Undang Hukum Pidana yakni:

1. kemampuan bertanggung jawab (Pasal 44);

2. daya paksa karena dorongan psikis (Pasal 48);

3. pembelaan terpaksa melampaui batas (Pasal 49 ayat(2)); dan

4. kesalahan yang dapat dimaafkan mengenai kewenangan atas dasar suatu perintah jabatan diberikan (Pasal 51 ayat (2)).

Adapun yang termasuk alasan penghapus sifat melawan hukum ialah:

1. daya paksa dalam arti keadaan darurat (Pasal 48);

2. daya paksa dalam arti terpaksa memilih antara kewajiban-kewajiban yang bertentangan (Pasal 48);

3. pembelaan terpaksa (Pasal 49 ayat (1));

4. peraturan perundang-undangan (Pasal 50); dan

5. Perintah Jabatan (Pasal 51 ayat (1)).

Kemampuan bertanggung jawab pada pelaku tindak pidana pornografi menurut Undang-Undang Nomor 44 Tahun 2008 tentang Pornografi pada dasarnya sama halnya dengan kemampuan bertanggung jawab pada tindak pidana pada umumnya. Hal ini di dasarkan karena di dalam Undang-Undang Nomor 44 Tahun 2008 tentang Pornografi tidak menjelaskan tentang kemampuan bertanggung jawab. Dalam ketentuan peralihan, menyatakan bahwa, "pada saat Undang-Undang ini mulai berlaku, semua peraturan perundang-undangan yang mengatur atau berkaitan dengan tindak pidana pornografi dinyatakan tetap berlaku sepanjang tidak bertentangan dengan Undang-Undang ini”. Oleh kerena itu mengenai pertanggungjawaban pidana pornografi ini di dasarkan dalam ketentuan Kitab Undang-Undang Hukum Pidana. Di dalam Kitab Undang-Undang Hukum Pidana menjelaskan tentang orang-orang yang tidak dapat dimintakan pertanggungjawabannya dalam tindak pidana pornografi yaitu orang yang cacat, yang belum dewasa, melaksanakan perintah jabatan dan Undang-Undang. Dalam hal ini orang yang dapat dipidana haruslah merupakan orang yang normal akalnya, tidak cacat jiwanya atau tidak hilang ingatan serta orang tersebut telah dewasa.

Dalam Undang-Undang Nomor 44 Tahun 2008, semua tindak pidana pornografi adalah tindak pidana dolus (sengaja). Namun, hanya tindak pidana Pasal 34 yang mencantumkan unsur dengan sengaja. Sementara itu, 
tindak pidana pornografi lainnya tidak. Meskipun tidak mencantumkan unsur sengaja dalam rumusan, tindak pidana pornografi lainnya merupakan tindak pidana sengaja. Dalam Undang-Undang Nomor 44 Tahun 2008 tentang Pornografi dicantumkan pengecualian dari larangan perbuatan yang masuk kategori tindak pidana. Pengecualian itu merupakan dasar peniadaan pidana khusus pornografi. Terdapat dalam Pasal 13 dan 14 yang memberikan kekhususan bagi majalah yang memuat model yang berpakaian bikini, baju renang, dan pakaian olahraga pantai, yang digunakan sesuai dengan konteksnya.

\section{Kelemahan Sistem Pertanggungjawaban Pelaku Tindak Pidana Pornografi Menurut Undang-Undang Nomor 44 Tahun 2008 tentang Pornografi}

Pertanggungjawaban pidana berhubungan erat dengan pemidanaan. Seseorang yang telah dinyatakan untuk mempertanggungjawabkan perbuatannya maka orang tersebut akan menjalankan pemidanaannya. Dalam Pemidanaan, maka salah satu unsur yang harus dipenuhi adalah subjek hukumnya. Biasanya di dalam berbagai rumusan disebutkan dengan istilah "barangsiapa" atau "setiap orang". Pada unsur "barangsiapa" memiliki cakupan yang lebih luas, tidak hanya manusia tapi juga bisa badan hukum. Sedangkan pada unsur "setiap orang" terbatas hanya kepada manusia sebagai subjek hukum.

Undang-Undang Pornografi ini menggunakan unsur " barangsiapa" yang mengatur pertanggungjawaban korporasi atau badan hukum. Sitem pemidanaan dalam Undang-Undang Pornografi ini menganut sistem pemberian sanksi minimal hal ini dapat menjadi indikator keseriusan pembuat undang-undang terhadap perkembangan permasalahan pornografi saat ini. Namun, undang-undang pornografi ini juga memiliki kelemahan yang sangat berpengaruh dalam penegakan hukumnya sebagai pertanggungjawaban pidana pornografi sebagai berikut:

\section{a. Unsur dalam Tindak Pidana Pornografi}

Pornografi adalah gambar, sketsa, ilustrasi, suara, bunyi, gambar bergerak, animasi, kartun, percakapan, gerak tubuh, atau bentuk pesan lainnya melalui berbagai bentuk media komunikasi dan atau pertunjukan di muka umum yang memuat kecabulan atau eksplorasi seksual yang melanggar norma kesusilaan dalam masyarakat. Dalam penjelasan Pasal 1 adalah cukup jelas. Tindak pidana pornografi merupakan tindak pidana kejahatan (Pasal39) dan unsur dalam tindak pidana pornografi adalah adanya kesengajaan. Memperhatikan Pasal 4 ayat (1) jo Pasal 29, dapat dirinci 
bahwa yang menjadi unsur dalam tindak pidana ada 2 (dua) yaitu perbuatan dan objeknya. Unsur perbuatan tindak pidana Pornografi, yaitu:

1) memproduksi;

2) membuat;

3) memperbanyak;

4) menggandakan;

5) menyebarluaskan;

6) menyiarkan;

7) mengimpor;

8) mengekspor;

9) menawarkan;

10) memperjualbelikan;

11) menyewakan;

12) menyediakan;

13) meminjamkan atau mengunduh;

14) memperdengarkan;

15) mempertontonkan;

16) memanfaatkan;

17) memiliki;

18) menyimpan;

19) mengajak;

20) membujuk;

21) memanfaatkan;

22) membiarkan;

23) melibatkan anak; dan

24) menyalahgunakan kuasa.

Dari perbuatan tindak pidana pornografi di atas terdapat tumpang tindih pengertian satu dengan yang lainnya seperti pengertian memproduksi dengan membuat, memperbanyak dengan menggandakan, menyebarluaskan dengan mengedarkan dan menjualbelikan. Hal ini juga diperjelas dalam penjelasan Pasal 13 ayat (1) yaitu:

1) yang dimaksud dengan "perbuatan" termasuk memproduksi, membuat, memperbanyak atau menggandakan; dan

2) yang dimaksud dengan "penggunaan" termasuk memperdengarkan, mempertontonkan, memanfaatkan, memiliki atau menyimpan.

Hal ini mempunyai akibat bahwa dalam satu kasus tertentu maka dapat diterapkan dua atau tiga perbuatan pidana sekaligus. Kekaburan dalam penerapan pasal sebagai pijakan terhadap semua peraturan dan hukum akan berpengaruh dalam menerapkan aturan hukum pada suatu peraturan yang konkret. 


\section{b. Pelaku Tindak Pidana Pornografi}

Pelaku tindak pidana pornografi adalah orang yang melakukan tindak pidana pornografi, namun dalam undang-undang pornografi ini masih memiliki kejanggalan dalam menentukan pelaku tindak pidana pornografi terkait sebagaimana yang di atur pada Pasal 8, 9, dan 11 UU Pornografi, Pasal 8 mengatur "setiap orang dilarang dengan sengaja atau persetujuan dirinya menjadi objek atau model yang mengandung muatan pornografi. Kemudian pasal 9 menyebutkan "setiap orang dilarang menjadikan orang lain sebagai objek atau model yang mengandung muatan pornografi". Selanjutnya pada pasal 11 mengatur bahwa "setiap orang dilarang melibatkan anak dalam kegiatan dan atau sebagai objek pornografi".

Unsur sengaja yang terdapat dalam Pasal 8 UUP ini "dengan sengaja". Unsur "dengan sengaja" merupakan unsur subjektif. Unsur subjektif yang berpengaruh dalam penentuan pelaku tindak pidana pornografi untuk pertanggungjawaban pidananya di mana dalam pemeriksaan di depan sidang, Jaksa Penuntut Umum (JPU) wajib membuktikan bahwa perilaku pelaku memenuhi unsur "dengan sengaja" (dolus/opzet atau kesengajaan) tersebut.

Untuk mengetahui unsur "dengan sengaja" maka harus terdiri beberapa indikasi, yaitu:

1) adanya niat atau kehendak yang disadari yang ditujukan untuk melakukan kejahatan tertentu;

2) adanya perbuatan permulaan;

3) perbuatan yang melanggar hukum; dan

4) adanya akibat dari perbuatannya.

Menurut doktrin Yurisprudensi menjelaskan unsur subjektif "dengan sengaja" adalah bahwa perbuatan yang dilakukan terdakwa tersebut dilakukan dengan sengaja atau terdakwa menyadari akan perbuatan yang dilakukannya akibat yang timbul dari perbuatannya.

\section{c. Makna Kata Mengunduh "download"}

Pengaturan untuk pengertian mengunduh sebagaimana yang diatur dalam Pasal 5 Undang-Undang Pornografi yaitu setiap orang dilarang meminjamkan atau mengunduh pornografi sebagaimana dimaksud Pasal 4 ayat (1). Dalam penjelasannya disebutkan bahwa yang dimaksud "mengunduh" (download) adalah mengambil fail (file) dari jaringan internet atau jaringan komunikasi lainnya. Mengenai pengertian mengunduh (download) tidak secara jelas disebutkan. Dalam mengunduh ada beberapa kegiatan yaitu mengunduh hanya sekedar melihat saja, mengopi, dan menyebarkan ke pihak lain. Jika memperhatikan Pasal 5 ini maka setiap orang yang mengunduh dan sekedar melihat adalah merupakan tindak pidana pornografi karena tidak ada pengecualian. 
Kemudian dalam hal pengertian "mengunduh" bagaimana sistem pengawasan dan implementasinya di lapangan. Setiap lembaga mempunyai kewenangan untuk melakukan pengawasan. Pada Pasal 17 dan 18 UUP yang mempunyai kewenangan untuk melakukan pengawasan adalah pemerintah pusat dan daerah tanpa menyebutkan secara ekplisit misalnya dibawah kewenangan Kementerian Telekomunikasi dan Informatika. Hal ini mengkhawatirkan akan menimbulkan bias hukum dan saling lempar tanggung jawab dan kewenangan.

\section{Penutup \\ 1. Kesimpulan}

Pertanggungjawaban Pelaku Tindak Pidana Pornografi menurut Undang-Undang Nomor 44 Tahun 2008 tentang Pornografi adalah merupakan pertanggungjawaban atas dasar kesalahan yang bersifat kesengajaan, namun tidak menutup kemungkinan adanya suatu kelalaian. Pertanggungjawaban pidana mengenai kemampuan bertanggung jawab tidak ditentukan khusus dalam undang-undang pornografi ini sehingga untuk menentukan pertanggungjawabannya dapat ditentukan berdasarkan ketentuan dalam Kitab Undang-Undang Hukum Pidana, yaitu Orang yang sakit ingatan (Pasal 44), Orang di bawah umur ( Pasal 45), Melaksanakan perintah jabatan (Pasal 45), dan Melaksanakan Undang-Undang (Pasal 50). Dalam hal ini orang yang dapat dipidana haruslah merupakan orang yang normal akalnya, tidak cacat jiwanya atau tidak hilang ingatan, serta orang tersebut telah dewasa. Undang-Undang Pornografi ini memiliki kekhususan dalam alasan penghapusan pidana, yaitu terdapat dalam Pasal 13 dan 14 yang memberikan kekhususan bagi majalah yang memuat model yang berpakaian bikini, baju renang, dan pakaian olahraga pantai, yang digunakan sesuai dengan konteksnya.

Kelemahan Sistem Pertanggungjawaban Pelaku Tindak Pidana Pornografi menurut Undang-Undang Nomor 44 Tahun 2008, karena adanya tumpang tindih pengertian satu dengan yang lainnya seperti pengertian memproduksi dengan membuat, memperbanyak dengan menggandakan, menyebarluaskan dengan mengedarkan dan memperjualbelikan. Undangundang ini memiliki kelemahan dalam menentukan pelaku tindak pidana terkait dengan pasal 8, 9, dan 11 UU Pornografi, Pasal 8 mengatur "setiap orang dilarang dengan sengaja atau persetujuan dirinya menjadi objek atau model yang mengandung muatan pornografi". Kemudian pasal 9 menyebutkan "setiap orang dilarang menjadikan orang lain sebagai objek atau model yang mengandung muatan pornografi". Selanjutnya pada pasal 11 mengatur bahwa " setiap orang dilarang melibatkan anak dalam kegiatan dan atau sebagai objek pornografi". Kelemahan juga karena tidak adanya definisi kata "mengunduh" atau "download" terkait dengan Pasal 5 yaitu 
setiap orang dilarang meminjamkan atau mengunduh pornografi sebagaimana dimaksud pasal 4 ayat 1 .

\section{Saran}

Pemerintah dalam hal ini untuk pembuat Undang-Undang Nomor 44 Tahun 2008 Pornografi ini disarankan tidak memberikan pengecualian terhadap dirinya sendiri dan kepentingan sendiri untuk tindak pidana dalam Pasal 4, serta melihat kembali unsur-unsur tindak pidana sehingga menghindari tumpang tindih pengertian. Masyarakat dapat bekerja sama dengan pemerintah membantu untuk upaya pemberantasan pornografi di lingkungan masyarakat kita, sehingga tercipta suasana yang aman, tertib, dan menciptakan generasi muda yang bermoral.

\section{Daftar Pustaka}

Chazawi, Adami, 2005. Tindak Pidana Mengenai Kesopanan, Malang: PT Grafindo Persada.

, 2009, Tindak Pidana Pornografi, Surabaya: Cv, Putra Media Nusantara.

Dwi Laning, Vina, 2008. Kenakalan Remaja dan Penangulangannya, Karanganom: Ciempaka Putih.

Erdianto, 2010. Pokok-Pokok Hukum Pidana, Pekanbaru: Alaf Riau Graha Unri Press.

Marpaung, Leden, 2008. Kejahatan Terhadap Kesusilaan, Jakarta: Sinar Grafika.

Moeljatno, 2008. Asas-Asas Hukum Pidana, Jakarta: Penerbit Rineka Cipta.

Soekanto, Soerjono, 1996. Pengantar Penelitian Hukum, Jakarta: UI-Press. 